\title{
Identification of Luwak coffee volatile compounds with gas chromatography- mass spectrometry (GC-MS) method
}

\author{
${ }^{1}$ Ifmalinda, ${ }^{2}$ Imas, S.S., ${ }^{2}$ Mimin, M. and ${ }^{2}$ Sarifah, N. \\ ${ }^{1}$ Department of Agricultural Engineering, Andalas University, West Sumatera 25163, Indonesia \\ ${ }^{2}$ Faculty of Agricultural Industry Technology, Padjadjaran University, Bandung 40132, Indonesia
}

\section{Article history:}

Received: 5 July 2018

Received in revised form: 19

August 2018

Accepted: 30 August 2018

Available Online: 6

November 2018

Keywords:

Jack bean,

Tempeh,

Physicochemical properties,

Functional properties

DOI:

https://doi.org/10.26656/fr.2017.2(6).121

\begin{abstract}
Luwak Coffee is considered high class coffee in the international market for its specialty taste. Aroma is one of the most important components of coffee. Coffee aroma compounds are volatile and non-volatile. Different volatile compounds can be caused by the different roasting level and the variety of coffee. One of approachment to detect the originality and volatile compounds of Luwak coffee and Arabica coffee is by analyzing their volatile compounds. The goal of this research was to detect the volatile compounds of Luwak coffee and Arabica coffee. This research was done in Pulo sari plantation, Pangalengan Bandung, and Laboratory of Health Polytechnic of Bandung, in January 2014. Gas Chromatography-Mass Spectrometry (GC-MS) was used to detect the volatile compounds. The results showed two volatile compounds can be distinguished from Luwak coffee from Arabica coffee, i.e. maltol and pyrazine 2,5 - dimethyl compounds.
\end{abstract}

\section{Introduction}

Coffee is a beverage that has the specialty taste. Other than its specialty taste, coffee can cause physical effects on humans i.e. freshness after consuming it. Because of that, coffee is enthused by the consumers all over the world. Generally, coffee is not consumed for its nutrients, but also for its taste and the physical effects.

Nowadays, Luwak coffee is popular. The coffee bean was taken from the civet's dung. This coffee is believed to have a specialty taste as the coffee fruit was eaten by civet and digested and excreted. The fermentation of the coffee fruit was done inside the civet's digestion system. It was researched that a change of the protein in the coffee bean was observed due to the proteolytic enzymatic reaction during digestion. Although the coffee has existed for a long time, it has just acknowledged as a gourmet coffee by consumers in the 1980s. The Luwak coffee bean is the most expensive coffee bean sold in the market approximately USD 100 per 450 grams. The beans are recognized to have a darker colour with hard texture.

One of the determiners of the chemical compounds of the coffee bean is the variety of coffee. Different variety of coffee has a different chemical profile which plays an important role in the taste and aroma of the coffee. The chemical compounds are volatile and nonvolatile compounds produced during the roasting process. At different levels of roasting, the chemical compounds produced also varies. In addition, different compound proportions can result in the different taste of coffee. Some consumers do not like the taste of the coffee because of these compounds, but other consumers can accept it. Moreover, coffee is also liked based on its aroma as well. One of the methods that can differentiate Luwak Coffee and Arabica Coffee is by analysing the volatile compounds of the coffee. This research is aimed to identify the volatile compounds present in Luwak Coffee and Arabica Coffee.

\section{Materials and methods}

This research was conducted in Pulo Sari Pangalengan Coffee Plantation and in the Laboratory of Health Polytechnic of Bandung, in January 2010. The method used for the identification of volatile compound in Luwak coffee and Arabica coffee is via Gas Chromatography-Mass Spectrometry (GC-MS). The sample was weighed up to $0.5 \mathrm{~g}$ and roasted as long as 20 mins with a temperature of $60-70^{\circ} \mathrm{C}$ so that the volatile compound inside the bean will be evaporated. The holder of SPME was inserted into the hollow tube so the volatile compound can be sucked into the GC-MS (Shimadzu, QP2010) with the following conditions: injector temperature $280^{\circ} \mathrm{C}$; mode splitless injector; column temperature $40^{\circ} \mathrm{C}\left(10^{\circ} \mathrm{C} /\right.$ minute $)$; retention time 3 minutes $\left(30^{\circ} \mathrm{C} /\right.$ minute) to reach the temperature of $299^{\circ} \mathrm{C}$ with total program time of 29,633 minutes; detector temperature $280^{\circ} \mathrm{C}$; Helium gas was used as the 
carrier gas; flow control mode pressure at 4.3367 psi; total of flow $8.4 \mathrm{~mL} / \mathrm{m}$; column current $0.9 \mathrm{~mL} / \mathrm{m}$; split ratio 5:1, column type Rtx-5MS; and column length $30.00 \mathrm{~m}$.

\section{Results and discussion}

Gas chromatography is a spectroscopic technique that uses the principle of separation of mixtures based on differences in the speed of migration of the constituent components. Gas chromatography is commonly used to identify a compound found in a gas mixture and also determine the concentration of a compound in the gas phase. In the GCMS analysis method (Gas Chromatography-Mass Spectroscopy) is by reading the spectra contained in the two combined methods. In GC spectra, if there is a sample of many compounds, it can be seen from the number of peaks in the GC spectra. Based on the retention time data that has been known from the literature, it can be known what compounds are in the sample. The chromatogram consists of a peak, where one peak represents a specific molecule. Minimal separation in GC systems is determined by various peaks or patterns in the chromatogram that correspond to different components of separate mixtures.

Figure 1 shows the chromatogram of the volatile compounds of roasted Arabica coffee. There are nine identified peaks. Two main peaks were found separated at RT 5.859 and RT 19.435 respectively. Subsequently, the other peaks were found at RT 4.849, 17.372 continued in RT 24.556.

Figure 2 shows the chromatogram of the volatile compounds of roasted Luwak coffee. There are seventeen identified peaks. Two main peaks were found separately at RT 5.859 and RT 19.452. Then the other fifteen peaks found in RT 4.510, 5.143, 5.807, 6.701, $7.221,9.110,12.006,17.380$ continued until RT 24.5567

The results of the volatile compound analysis of arabica and Luwak coffee separated via GC-MS were shown in Table 1.

Volatile compounds are compounds that can be easily evaporated, especially with the increment of temperature. The volatile compounds that produce the aroma of coffee are aldehyde, ketone, and alcohol. The main difference between Arabica and Luwak coffee was the identification of maltol and pyrazine 2,5-dimethyl from Luwak coffee and found absent in the Arabica coffee.

The maltol compound is a chemical compound with a sugary flavor or cotton candy-like flavour, often used as flavour enhancer in food and beverage products. Meanwhile, the pyrazine compound that identified from the Luwak coffee is the compound that constructed the chocolate aroma.

Our results differed from the results obtained from other researchers due to the different methods of identifying the volatile compounds of Luwak coffee. Sari et al. (2012) conducted an analysis of volatile compounds identification of Luwak coffee using microextraction solid phase and chromatographic gas. Citric acid, malic acid inositol and the ratio of pyroglutamic acid were chosen for verification compared to several commercial products.

The class of volatile compounds contained in the Luwak coffee and Arabic coffee were aldehyde, ketone (2-propane, 1-acetyloxy), furan (2-furanmethanol, Butyrolactone, 2-furanmethanol acetate) compounds. The classes identified were in the agreement with Fuster et al. (2000). Pestica et al. (2013) stated there were around 1000 volatile compounds that have been identified from roasted coffee. Those consist of pyrazine, aldehyde, ketone, phenol, pyridine, pyrrole, furan, pyrone, amine, thiazole, oxazole, alcohol, benzene, ester and organic acid.

The classes of volatile compound that constructed the aroma of the coffee were carbonyl compounds (aldehyde and hydrocarbon (2-furancarboxaldehyde, 5methyl), furfural compounds, furan compounds (2propane, 1-(acetyloxy), and ester compounds (1,2(benzene dicarboxylic acid). The results were similar to Mulato (2002). Mulato (2002) added that natural coffee bean contains several types of volatile compounds that have evaporation property such as aldehyde, furfural, ketone, alcohol, ester, formic acid, and acetate acid.

Carbonyl compounds that have the lower molecular weight, i.e methanol, and aldehyde, produce a spicy aroma. Volatile compounds of the hydrocarbon class that was detected in the sample is a homologue compound from hydrocarbon cyclic and straight line chain. Alkane hydrocarbon cluster has the saturated chain that can be resulted from decarboxylation and disintegration of coron chains from high fatty acid chains. Alkane class are derivated from decarboxylation and disintegration of fatty acid chains (Chung et al., 2002; Linda and Ackman, 2002).

\section{Conclusion}

There are some differences between the volatile compounds of Luwak and Arabica coffee. The main difference between Arabica and Luwak coffee was the two compounds, maltol and pyrazine 2,5-dimethyl compounds found that were absent in Arabica coffee. 


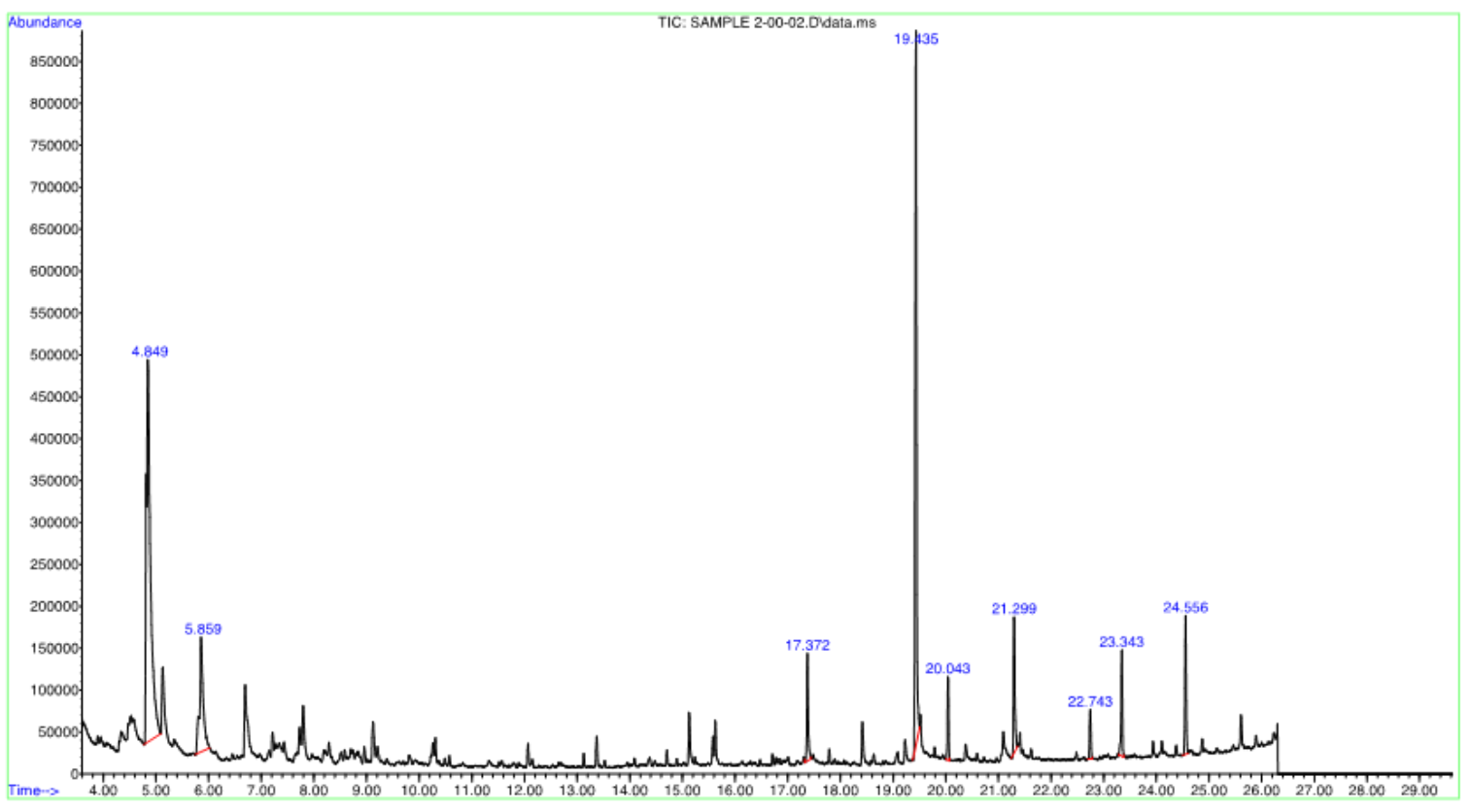

Figure 1. Chromatogram of the volatile compounds of roasted Arabica coffee

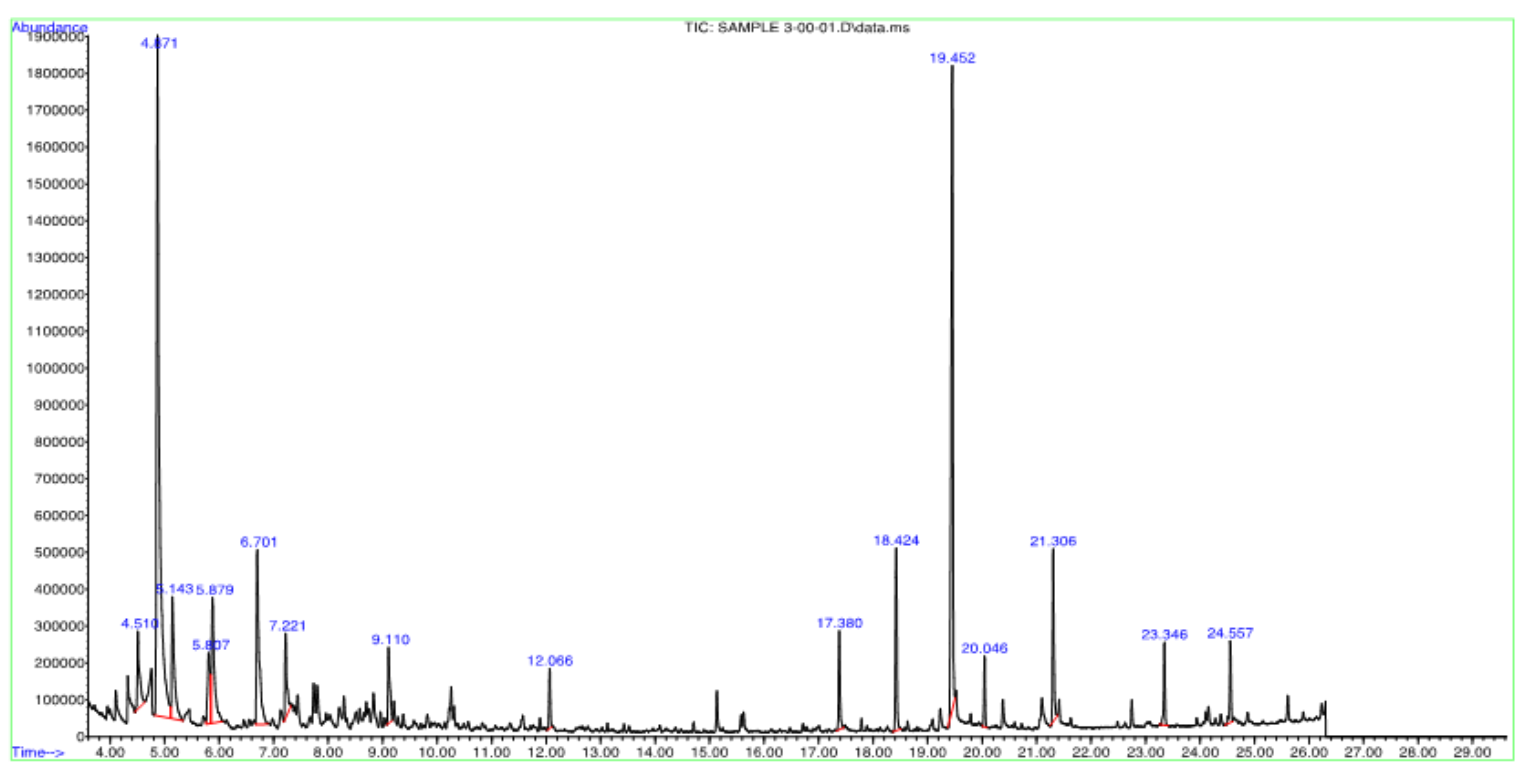

Figure 2. Chromatogram of the volatile compounds of roasted Luwak coffee

Table 1. Volatile Compounds that detected in Arabica and Luwak coffee

\begin{tabular}{clclc}
\hline No & \multicolumn{1}{c}{ Arabica coffee } & \% Area & Luwak coffee & \% Area \\
\hline 1 & Furfural & 2.68 & Furfural & 2.89 \\
2 & 2-Furanmethanol & 22.04 & 2-Furanmethanol & 32.66 \\
3 & 2-Propanone, 1-(acetyloxy)- & 3.12 & 2-Propanone, 1-(acetyloxy)- & 5.56 \\
4 & Butyrolactone & 4.03 & Butyrolactone & 6.28 \\
5 & 2-Furancarboxaldehyde, 5-methyl- & 2.34 & 2-Furancarboxaldehyde, 5-methyl & 7.78 \\
6 & 2-Furanmethanol, acetate & 1.92 & 2-Furanmethanol, acetate & 1.37 \\
7 & 1,2-Benzenedicarboxylic acid, diisooctyl ester & 2.19 & $\begin{array}{l}\text { 1,2-Benzenedicarboxylic acid, mono(2- } \\
\text { ethylhexyl) ester }\end{array}$ & 2.00 \\
8 & - & - & Pyrazine 2,5 -dimethyl & 3.17 \\
9 & - & - & Maltol & 2.77 \\
\hline
\end{tabular}




\section{References}

Chung, H.Y., Yung, I.K.S., Ma, W.C.J. and Kim, J.-S. (2002). Analysis of Volatile Components in Frozen and Dried Scallops (Patinopecten Yessoensis) by Gas Chromatography-Mass Spectrometry. Food Research International, 35(1), 43-53. https:// doi.org/10.1016/S0963-9969(01)00107-7

Fuster, M.D., Mitchell, A.E., Ochi, H. and Shibamoto, T. (2000). Antioxidative Activities of Heterocyclic Compounds Formed in Brewed Coffee. Journal of Agricultural and Food Chemistry, 48(11), 56005603. https://doi.org/10.1021/jf000605e

Linder, M. and Ackman, R.G. (2002). Volatile Compounds Recovered by Solid-Phase Microextraction from Fresh Adductor Muscle and Total Lipids of Sea Scallop (Placopecten magellanicus) from Georges Bank (Nova Scotia). Journal of Food Science, 67(6), 2032-2037. https:// doi.org/10.1111/j.1365-2621.2002.tb09496.x

Mulato, S. (2002). Simposium Kopi 2002 dengan tema Mewujudkan perkopian Nasional Yang Tangguh melalui Diversifikasi Usaha Berwawasan Lingkungan dalam Pengembangan Industri Kopi Bubuk Skala Kecil Untuk Meningkatkan Nilai Tambah Usaha Tani Kopi Rakyat, 16 - 17 October 2002. Denpasar, Indonesia: Pusat Penelitian Kopi dan Kakao Indonesia [In Bahasa Indonesia].

Petisca, C, Trinidad, P.-P., Farah, A. Pinho, O. and Ferreira, I.M.P.L.V.O. (2013). Furans and Other Volatile Compounds in Ground Roasted and Espresso Coffee using Headspace Solid-Phase Microextraction: Effect of Roasting Speed. Food and Bioproducts Processing, 9(3), 233-241. https:// doi.org/10.1016/j.fbp.2012.10.003

Sari, A.B.T., Ismayadi, C., Wahyudi, T. and Sulihkanti, A. (2012). Analysis of Luwak coffee volatile by using solid phase microextraction and gas chromatography. Pelita Pekebunan, 28(2), 111-118. 